\title{
Evaluasi Program In-Service Training Guru SMK di BLPT Yogyakarta
}

\author{
Sumiharyati ${ }^{1, *}$, Suharsimi Arikunto ${ }^{2}$ \\ ${ }^{1}$ SMK N 1 Pajangan, Bantul, Indonesia \\ ${ }^{2}$ Universitas Negeri Yogyakarta, Yogyakarta, Indonesia \\ *Corresponding Author. Email: harryatiqu@ gmail.com
}

\begin{abstract}
Abstrak
Penelitian ini bertujuan untuk mengevaluasi keberhasilan program In-service Training guru SMK di BLPT Yogyakarta yang terkait dengan komponen konteks, input, proses dan produk khususnya jurusan sipil dan furniture. Penelitian ini merupakan evaluasi ex-post facto model evaluasi Context, Input, Process, and Product (CIPP) dengan menggunakan pendekatan kuantitatif. Subyek penelitian ini adalah 56 guru SMK Jurusan Sipil dan Furniture di DIY yang telah mengikuti program In-service Training guru SMK di BLPT Yogyakarta. Data dikumpulkan melalui kuesioner yang divalidasi dengan uji validitas corrected item total yang identik dengan korelasi product moment, serta lolos uji reliabilitas alpha cronbach. Teknik analisis data yang digunakan adalah statistik kuantitatif dengan kriteria. Hasil penelitian menunjukkan bahwa 87,5\% responden menyatakan program In-service Training guru SMK di BLPT Yogyakarta cukup bermanfaat dalam meningkatkan pengetahuan dan keterampilan peserta. Berdasarkan hasil penelitian dapat disimpulkan bahwa: 1) Komponen konteks yang berkaitan dengan relevansi program mencapai rerata skor 2,94 dengan kategori baik; 2) Komponen input mencapai rerata skor 2,99 dengan kategori baik; 3) Komponen proses mencapai rerata skor 2,90 dengan kategori baik; dan 4) Pelaksanaan program In-service Training di BLPT Yogyakarta bermanfaat dalam meningkatkan pengetahuan dan keterampilan guru terbukti dengan rerata skor yang mencapai 3,17 dengan kategori baik.
\end{abstract}

Kata kunci: Evaluasi Program, In-Service Training, Kompetensi Guru.

\section{Evaluation of an In-Service Training Program for Vocational Teachers in BLPT Yogyakarta}

\begin{abstract}
This research aimed at evaluating the success of an in-service training program vocational teachers' in BLPT Yogyakarta related to components of context, input, process, and product, particularly on Civil and Furniture study program. This research belonged to ex-post facto CIPP (Context, Input, Process, and Product) model using quantitative approach. The subjects of this study were 56 Vocational teachers of Civil and Furniture study program who had completed in-service training in BLPT Yogyakarta. Data were collected through questionnaire validated by running corrected item-total test, identical to product-moment correlation, and passed reliability test of cronbach's alpha. The data were statistically and quantitatively analyzed based on criteria. The result showed that $87,5 \%$ of respondents stated that the In-Service Training program for vocational svhool teachers in BLPT Yogyakarta was quite useful in increasing the knowledge and skills of participants. Based on the result of the study it can be concluded that: 1) Context component related to the relevance of program gained mean score 2.94 categorized as 'good'; 2) Input component obtained mean score 2.99 classified as 'good'; 3) Process component achieved mean score 2.90 considered as 'good'; and 4) In-service training program conducted in BLPT Yogyakarta promotes teachers' knowledge and skills demonstrated by the mean score 3.17 categorized as 'good'.
\end{abstract}

Keywords: Program Evaluation, In-Service Training, Teacher Competence. 


\section{PENDAHULUAN}

Pendidikan merupakan sarana bagi seseorang untuk mencapai tujuannya, hal ini sesuai dengan Sistem Pendidikan Nasional yang tertuang dalam Undang-Undang Nomor 20 Tahun 2003 tentang Sistem Pendidikan Nasional pasal 1 ayat 1 disebutkan bahwa pendidikan adalah usaha sadar dan terencana untuk mewujudkan suasana belajar dan proses pembelajaran agar peserta didik secara aktif mengembangkan potensi dirinya untuk memiliki kekuatan spiritual keagamaan, pengendalian diri, kepribadian, kecerdasan, akhlak mulia, serta ketrampilan yang diperlukan dirinya, masyarakat, bangsa dan agama. Pembelajaran merupakan susunan dari beberapa unsur yang terdiri dari pelaku dalam proses pembelajaran, bahan ajar, fasilitas belajar yang saling mempengaruhi untuk mencapai tujuan (Hamalik, 2014, p.57).

Pelatihan pada umumnya diasosiasikan pada upaya mempersiapkan seseorang dalam melaksanakan suatu tugas pada pekerjaannya. Pelatihan juga dapat dipantau sebagai elemen khusus dari proses pendidikan. Hal ini sesuai dengan penelitian yang dilakukan oleh Jahangir, Saheen, dan Kazmi (2012, p. 36) yang menyatakan pelatihan bagi guru merupakan hal yang penting dalam meningkatkan kompetensi yang dimilikinya. Semakin guru banyak mengikuti pelatihan yang bermutu, maka akan semakin baik pula kompetensi yang dimilikinya untuk mendidik generasi penerus yang lebih baik di masa depan.

Namun kenyataan tidak semua pelatihan yang diikuti oleh guru sesuai dengan kebutuhan guru. Hal ini sesuai dengan pernyataan Wijaya pada Harian KOMPAS pada tanggal 7 Juli 2015 bahwa materi yang diberikan kepada guru pada saat pelatihan atau diklat belum tentu sesuai dengan materi yang diajarkan kepada siswa. Berdasarkan pernyataan dan pendapat tersebut dapat disimpulkan pelatihan yang diselenggarakan oleh pemerintah atau lembaga untuk guru belum semuanya dapat memenuhi kebutuhan guru untuk dapat mengembangkan pembelajaran yang sesuai dengan pelajaran yang diampunya di sekolah.

Kendala lain yang dihadapi oleh guru untuk mengikuti pelatihan adalah jumlah pelatihan yang dilaksanakan tidak sebanding dengan jumlah guru yang ada sebagaimana yang dinyatakan oleh ketua umum PGRI Sulistiyo yang dimuat dalam Harian KOMPAS tanggal 1 Agustus 2015 mengemukakan pemerintah belum secara sistematis mengupayakan peningkatan kompetensi guru. Hal tersebut dapat dilihat dari jumlah pelatihan yang diadakan oleh pemerintah atau lembaga setiap tahunnya hanya sekitar 500 guru yang berkesempatan mengikuti pelatihan, sedangkan jumlah guru satu kabupaten atau kota sekitar 10.000 guru.

Hasil observasi pada beberapa guru yang telah mengikuti program In-service Training (diklat dalam jabatan) di BLPT Yogyakarta menyatakan sebagai berikut: 1) Penunjukan peserta tidak berdasarkan analisis kebutuhan artinya lembaga diklat yang menunjuk pesertanya secara langsung (by name); 2) Kompetensi yang dimiliki peserta tidak sesuai dengan program In-service Training yang diikuti; 3) Kurikulum yang digunakan pada program In-service Training tidak sesuai dengan kurikulum yang digunakan di sekolah; 4) Metode yang digunakan pada pelaksanaan program In-service Training tidak sesuai dengan materi yang diberikan; 5) Materi yang diajarkan pada progrm In-service Training tidak berdasarkan kurikulum yang berlaku di sekolah, tetapi berdasarkan program yang telah ditetapkan oleh pemerintah atau pejabat yang berwenang, hasil program In-service Training yang dilaksanakan oleh guru belum tentu dapat dilaksanakan di sekolah.

Berdasarkan beberapa pernyataan di atas dapat dikatakan guru merupakan ujung tombak keberhasilan pendidikan. Oleh karena itu seorang guru harus berkompeten dalam bidangnya. Kompeten pada konteks ini dimaksudkan bahwa seorang guru selain memiliki pengetahuan juga harus memiliki keterampilan, pengalaman di lapangan, dan berusaha untuk menambah wawasan sesuai dengan kemajuan ilmu pengetahuan dan teknologi.

Seorang guru harus memiliki kompetensi profesional atau kompetensi yang sesuai dengan bidang tugasnya untuk kemajuan dan keberhasilan dalam pembelajaran siswanya, 
terlebih pada guru SMK (Sekolah Menengah Kejuruan) yang harus membekali siswanya dengan keahlian khusus agar mampu bekerja pada bidang tertentu. Hal ini sesuai dengan penjelasan atas Undang-Undang Nomor 20 Tahun 2003 pasal 15 tentang Sistem Pendidikan Nasional disebutkan bahwa "Pendidikan kejuruan merupakan pendidikan yang mempersiapkan peserta didik terutama untuk bekerja pada bidang tertentu". Oleh karena itu, seorang guru secara sadar harus berusaha untuk menambah pengetahuan dan keterampilan yang dimilikinya melalui pendidikan ataupun pelatihan yang sesuai dengan kompetensi yang dimilikinya. Selain itu seorang guru juga harus peka terhadap perkembangan ilmu pengetahuan dan teknologi yang terjadi di masyarakat.

Pendidikan dalam jabatan (In-service Training) sangat dibutuhkan oleh guru dalam usaha meningkatkan kompetensi-nya terlebih bagi guru SMK, melihat persaingan pengetahuan dan teknologi pada dunia global saat ini. Hal ini sesuai dengan hasil penelitian yang dilakukan oleh Gumbo, dkk. (2010) yang menyatakan pentingnya program In-service Training di bidang teknologi bagi guru bidang teknologi, karena guru merasa diuntung- kan dengan adanya pelatihan teknologi yang sesuai dengan kebutuhan mereka, dan pelatihan yang mereka ikuti dapat meningkatkan pengetahuan dan keterampilan, serta pemahaman tentang teknologi yang sesuai dengan bidangnya masing-masing.

Berbagai upaya telah dilakukan oleh pemerintah dalam rangka meningkatkan mutu pendidikan nasional antara lain melalui berbagai pelatihan dan peningkatan kompetensi guru, pengadaan buku, alat - alat pembelajaran, perbaikan sarana dan prasarana pendidikan, serta peningkatan mutu manajemen sekolah, sesuai kemajuan ilmu pengetahuan dan teknologi yang ada. Namun demikian mutu guru di Indonesia masih belum sesuai yang yang diharapkan sebagaimana yang ditulis Napitupulu (2015) pada Harian KOMPAS tanggal 7 Juli yang menyatakan dari hasil uji kompetensi yang dilakukan terhadap sekitar 1,6 juta guru sebagian besar nilainya di bawah 50 dari nilai tertinggi 100 .

Melihat kenyataan ini, pemerintah menyusun program pembinaan dan pengembangan profesi. Program pengembangan profesi diwujudkan melalui program peningkatan kompetensi guru pembelajar (GP) yang bertujuan untuk meningkatkan kompetensi guru sebagai agen perubahan dan menaikkan skor Uji Kompetensi Guru (UKG). Pelaksanaan peningkatan kompetensi pada pogram Guru Pembelajar terdiri tiga moda yaitu: 1) Moda tatap muka disarankan bagi guru yang rapornya merah sebanyak 8 sampai 10 modul kompetensi belum dikuasai; 2) Moda daring kombinasi disarankan bagi guru yang rapornya merah sebanyak 6 sampai 7 modul kompetensi belum dikuasai; dan 3) Moda daring disarankan bagi guru yang rapornya merah sebanyak 3 sampai 5 modul kompetensi belum dikuasai.

Moda Guru Pembelajar tersebut bukanlah batasan yang kaku. Hal ini mengingat dengan pertimbangan jumlah guru dalam satu rombongan belajar dalam satu mata pelajaran atau paket keahlian, segi geografis, dan anggaran yang disediakan. Selain tiga moda pada program Guru Pembelajar, pemerintah menghimbau agar masing-masing guru diwajibkan untuk terus belajar secara mandiri untuk meningkatkan kompetensi yang dimilikinya. Penyediaan fasilitas pelatihan yang disediakan oleh pemerintah bekerja sama dengan pemerintah daerah antara lain: LPMP (Lembaga Penjaminan Mutu Pendidikan), BLPT (Balai Latihan Pendidikan Teknik), P4TK (Pusat Pengembangan dan Pemberdayaan Pendidik dan Tenaga Kependidikan).

Pelatihan pada umumnya diasosiasikan pada upaya mempersiapkan seseorang dalam melaksanakan suatu tugas pada pekerjaannya. Pelatihan juga dapat dipantau sebagai elemen khusus dari proses pendidikan. Hal ini sesuai dengan penelitian yang dilakukan oleh Jahangir, Saheen, \& Kazmi (2012: 36) yang menyatakan pelatihan bagi guru merupakan hal yang penting dalam meningkatkan kompetensi yang dimilikinya. Semakin guru banyak mengikuti pelatihan yang bermutu, maka akan semakin baik pula kompetensi yang dimilikinya untuk mendidik generasi penerus yang lebih baik di masa depan. 
Dampak program In-service Training yang berpegaruh terhadap peningkatan profesional guru secara signifikan diteliti oleh Aziz, dkk (2016) di Pakistan. Hasil penelitian menunjukkan guru yang mengikuti pelatihan lebih kompeten di banding guru yang tidak terlatih, baik dalam hal kompetensi pedagogik, manajemen, kompetensi penilaian, kompetensi penelitian.

Berdasarkan pendapat dan hasil penelitian yang dilakukan sebelumnya, maka BLPT (Balai Latihan Pendidikan Teknik) merupakan salah satu solusi pemerintah dalam upaya untuk meningkatkan kompetensi profesional guru SMK. Program In-service Training guru SMK pada penelitian ini dilaksanakan di BLPT Yogyakarta. BLPT Yogyakarta merupakan Balai Latihan Pendidikan Teknik yang diresmikan oleh Menteri Pendidikan dan Kebudayaan Republik Indonesia pada tanggal 31 Maret 1981 bersama dengan 3 BLPT lainnya, yaitu BLPT Padang, BLPT Palembang, dan BLPT Semarang. Tujuan didirikannya BLPT adalah sebagai tempat praktik siswa-siswa STM (sekarang menjadi SMK) 3 tahun yang dipusatkan dalam satu komplek, sehingga penyelenggaraannya lebih efektif dan efisien.

Sejak diberlakukannya Otonomi Daerah Tahun 2001, maka BLPT diserahkan kepada Pemerintah Daerah sebagai Unit Pelaksana Teknis Daerah (UPTD) di bawah Dinas Pendidikan. Sejak saat itu BLPT dikembangkan tugas pokok dan fungsinya untuk melyani pendidikan dan pelatihan bagi Sekolah Menengah Kejuruan (SMK) Negeri/Swasta, Perguruan Tinggi Negeri/Swasta, Instansi/Lembaga, Dunia Usaha/Dunia Industri dan masyarakat umum. BLPT senantiasa berupaya untuk mendukung tugas tersebut dengan senantiasa meningkatkan kompetensi serta kinerja guna meningkatkan mutu pelayanan, baik dari segi peningkatan kompetensi sumber daya manusia maupun dari segi peralatan/ mesin praktik yang selalu disesuaikan dengan kebutuhan perkembangan teknologi saat ini.

Berdasarkan uraian di atas dan menyadari demikian kompleksnya faktor-faktor yang berhubungan dengan kompetensi profesional guru, maka perlu diteliti seberapa tinggi keberhasilan program In-service Training guru SMK yang diselenggarakan di BLPT Yogyakarta.

Rumusan masalah dalam penelitian ini adalah: Seberapa tinggi relevansi isi program Inservice Training guru SMK yang diselenggarakan di BLPT Yogyakarta terhadap kebutuhan peserta? Seberapa tinggi efektifitas input terkait dengan karakteritik peserta, instruktur, materi, dan sarana prasarana terhadap program In-service Training guru SMK di BLPT Yogyakarta? Seberapa tinggi efektifitas proses pelatihan terkait jadwal kegiatan, partisipasi peserta, media pembelajaran, metode pembelajaran, dan evaluasi pembelajaran pada program In-service Training guru SMK di BLPT Yogyakarta? Seberapa tinggi manfaat program Inservice Training guru SMK di BLPT Yogyakarta bagi peserta?

Berdasarkan rumusan masalah yang telah diuraikan sebelumnya, maka penelitian ini bertujuan untuk: 1) Mengetahui seberapa tinggi relevansi isi program terhadap kebutuhan guru/peserta program In-service Training guru SMK di BLPT Yogyakarta khususnya Jurusan Sipil dan Furniture; 2) Mengetahui seberapa tinggi efektifitas input terkait dengan karakteristik peserta, instruktur, materi, dan sarana prasarana yang ada terhadap program guru SMK di BLPT Yogyakarta khususnya Jurusan Sipil dan Furniture; 3) Mengetahui seberapa tinggi efektifitas proses pelatihan terkait jadwal kegiatan, partisipasi peserta, media pembelajaran, metode pembelajaran, dan evaluasi pembelajaran pada program In-service Training guru SMK di BLPT Yogyakarta, dan 4) Mengetahui seberapa tinggi manfaat program In-service Training guru SMK di BLPT Yogyakarta bagi peserta.

Hasil penelitian ini diharapkan dapat memberikan manfaat sebagai berikut: 1) Secara umum dari hasil penelitian ini diharapkan dapat menambah kepustakaan bagi peneliti yang melakukan penelitian yang berkaitan dengan program In-service Training (pelatihan dalam jabatan) yang diselenggarakan bagi guru; 2) Penelitian ini juga diharapkan mampu memberi masukan atau sebagai bahan perbandingan bagi peneliti lain yang melaksanakan penelitian 
sejenis; dan 3) Mampu memberi informasi yang aktual sebagai bahan masukan bagi pihakpihak terkait untuk dapat lebih meningkatkan kualitas penyelenggaraan program In-service Training agar bermanfaat dan sesuai dengan kebutuhan peserta.

\section{METODE PENELITIAN}

Ditinjau dari tujuannya, penelitian ini termasuk evaluasi program yaitu untuk mengevaluasi pelaksanaan program In-service Training guru SMK yang diselenggarakan di BLPT Yogyakarta Jurusan Sipil dan Furniture. Namun ditinjau dari variabelnya termasuk ex post facto, menurut Suharsimi (2010, p.17), penelitian ex post facto adalah penelitian yang dilakukan setelah program atau kegiatan yang diteliti telah berlangsung beberapa waktu yang lalu.

Model evaluasi dalam penelitian ini adalah CIPP (konteks, input, proses, produk) dengan pendekatan kuesioner (angket). Kuesioner pada penelitian ini dengan model penskoran. Penggunaan model CIPP (konteks, input, proses, produk) ini dimaksudkan untuk mengetahui tingkat keberhasilan pelaksanaan program In-service Training guru SMK yang dilaksanakan di BLPT Yogyakarta khususnya Jurusan Sipil dan Furniture. Hal ini dilakukan guna perbaikan dan peningkatan pelaksanaan program selanjutnya.

Penelitian dilakukan di seluruh SMK (Sekolah Menengah Kejuruan) Provinsi Daerah Istimewa Yogakarta yang gurunya telah melaksanakan program In-service Training guru SMK di BLPT Yogyakarta dengan dana APBD khususnya Jurusan Sipil dan Furnture. Mengingat banyaknya jumlah SMK (Sekolah Menengah Kejuruan) di Propensi Daerah Istimewa Yogyakarta yang akan dijadikan lokasi penelitian, maka peneliti mengadakan penelitian pada Bulan Januari 2017 sampai dengan Bulan Maret 2017.

Populasi pada penelitian ini terdiri dari semua guru SMK (Sekolah Menengah Kejuruan) bidang studi Rekayasa dan Teknologi khususnya Jurusan Sipil dan Furniture di Daerah Istimewa Yogyakarta yang telah mengikuti program In-service Training guru SMK di BLPT Yogyakarta. Subyek penelitian berjumlah 56 orang, yang terdiri dari: Teknik Autocad (13 orang), Teknik Ukur Tanah (11 orang), Teknik Perkayuan (16 orang), dan Teknik Finishing Kayu (16 orang).

Sesuai dengan teknik pengumpulan data dan teknik penyusunan instrumen, maka instrumen penelitian ini menggunakan angket (tabel 1). Angket/kuesioner penelitian dibuat dalam bentuk checklist yang sudah disediakan jawabannya, sehingga responden tinggal memilih. Angket diberikan pada responden yang telah mengikuti program In-service Training guru SMK di BLPT Yogyakarta Jurusan Sipil dan Furniture. Fakta yang akan diungkap dan dari mana sumber data yang diperoleh dijelaskan dalam tabel tentang komponen, sub komponen penelitian serta kaitan antara indikator, sumber data, metode, dan instrumen.

Metode yang digunakan dalam penelitian ini adalah metode evaluasi dengan kriteria, yaitu mendeskripsikan dan memaknai data tiap-tiap komponen evaluasi, kemudian dibandingkan dengan acuan kriteria yang telah ditentukan berdasarkan rata-rata ideal dan simpangan baku ideal yang dicapai instrumen. Analisis data yang dilakukan terbatas pada teknik pengolahan datanya, seperti pengecekan data dan tabulasi, serta analisis data dengan standar pengukuran tendensi sentral, yang ada kemudian di skor yang didapat dijumlahkan, dan dengan bantuan program komputer SPSS 21 untuk mendapatkan distribusi frekuensi, mean, median dan simpangan baku (SB). 
Tabel 1. Instrumen variabel

\begin{tabular}{|c|c|c|}
\hline No & Komponen & $\begin{array}{c}\text { Sub } \\
\text { Komponen }\end{array}$ \\
\hline 1 & Konteks & $\begin{array}{l}\text { Relevansi isi program dengan } \\
\text { kebutuhan peserta }\end{array}$ \\
\hline 2 & Input & $\begin{array}{l}\text { - Karakteristik peserta } \\
\text { - Instruktur } \\
\text { - Materi } \\
\text { - Sarana dan Prasarana }\end{array}$ \\
\hline 3 & Proses & $\begin{array}{l}\text { - Jadwal } \\
\text { - Partisipasi peserta } \\
\text { - Media } \\
\text { - Metode } \\
\text { - Evaluasi pembelajaran }\end{array}$ \\
\hline 4 & Produk & Manfaat program \\
\hline
\end{tabular}

Pengkatagorian dari kuesioner pilihan ganda yang didasarkan pada kurve normal, kemudian dikelompokkan ke dalam lima kategori yang mengacu pada pendapat Thoha (2003, pp. 100-101), yaitu sebagai berikut:

1. $\mathrm{X} \geq \mathrm{M}_{\mathrm{i}}+\left(1,5 \mathrm{SD}_{\mathrm{i}}\right)$ kategori sangat baik

2. $\mathrm{M}_{\mathrm{i}}+\left(0,5 \mathrm{SD}_{\mathrm{i}}\right) \leq \mathrm{X}<\mathrm{M}_{\mathrm{i}}+\left(1,5 \mathrm{SD}_{\mathrm{i}}\right)$ kategori baik

3. $\mathrm{M}_{\mathrm{i}}-\left(0,5 \mathrm{SD}_{\mathrm{i}}\right) \leq \mathrm{X}<\mathrm{M}_{\mathrm{i}}+\left(0,5 \mathrm{SD}_{\mathrm{i}}\right)$ kategori cukup baik

4. $\mathrm{M}_{\mathrm{i}}-\left(1,5 \mathrm{SD}_{\mathrm{i}}\right) \leq \mathrm{X}<\mathrm{M}_{\mathrm{i}}-\left(0,5 \mathrm{SD}_{\mathrm{i}}\right)$ kategori kurang baik

5. $\mathrm{X}<\mathrm{M}_{\mathrm{i}}-\left(1,5 \mathrm{SD}_{\mathrm{i}}\right)$ kategori tidak baik

Keterangan:

$\mathrm{X}=$ Skor yang diperoleh

$\mathrm{M}_{\mathrm{i}}=$ rata-rata ideal setiap komponen dalam penelitian dengan rumus:

$1 / 2\left(X_{\text {imaks }}+X_{\text {i min }}\right)$

$\mathrm{SD}_{\mathrm{i}}=$ deviasi ideal dalam setiap komponen penelitian dengan rumus:

1/6 ( $\left.\mathrm{X}_{\mathrm{i} \text { maks }}-\mathrm{X}_{\mathrm{imin}}\right)$

$\mathrm{X}_{\text {imaks }}=$ skor ideal tertinggi dalam komponen

$\mathrm{X}_{\text {imin }}=$ skor ideal terendah dalam komponen.

Menurut Arikunto \& Jabar (2014, pp. 30-35) kriteria atau standar adalah sesuatu yang digunakan sebagai patokan yang menunjukkan tingkatan dari sesuatu yang diukur. Kriteria keberhasilan pada penelitian ada dua macam, yaitu kriteria kualitatif dan kriteria kuantitatif. Kriteria kuantitatif dibedakan menjadi dua, yaitu kriteria tanpa pertimbangan dan kriteria dengan pertimbangan. Kriteria keberhasilan pada penelitian ini menggunakan kriteria kuantitatif tanpa pertimbangan artinya kriteria disusun hanya berdasarkan rentangan bilangan atau skor $(\mathrm{X})$ yang diperoleh dari analisis data, dimana skor tertinggi ideal $\left(\mathrm{X}_{\text {maks }}\right)$ adalah 4 dan skor terendah $\left(\mathrm{X}_{\min }\right)$ sehingga didapat kriteria keberhasilan sebagai berikut:

1. Sangat baik, jika memiliki skor lebih besar atau sama dengan 3,25

2. Baik, jika memiliki skor lebih dari atau sama dengan 2,75 dan kurang dari 3,25

3. Cukup baik, jika memiliki skor lebih dari atau sama dngan 2,25 dan kurang dari 2,75

4. Kurang baik, jika memiliki skor lebih dari atau sama dengan 1,75 dan kurang dari 2,25

5. Tidak baik, jika memiliki skor kurang dari 1,75

\section{HASIL DAN PEMBAHASAN}

Hasil analisis merupakan hasil pengolahan data dari angket penelitian yang diberikan kepada peserta program In-service training guru SMK DIY di BLPT Yogyakarta jurusan Sipil dan 
Furniture. Data penelitian dianalisis dengan menggunakan statistik deskriptif, sehingga diperoleh nilai dari masing- masing aspek evaluasi program In-service Training. Hasil analisis penelitian selengkapnya dijabarkan berikut ini:

Komponen konteks pada instrumen penelitian adalah relevansi isi program In-service Training guru SMK yang dilaksanakan di BLPT Yogyakarta terhadap kebutuhan peserta. Aspek konteks terdiri dari tiga indikator, yaitu:

1. Relevansi isi program dengan mata pelajaran yang diampu oleh peserta di sekolah.

2. Relevansi isi program dengan kurikulum yang digunakan di sekolah

3. Relevansi isi program dengan inovasi pembelajaran

Berdasarkan data yang diperoleh melalui 56 responden yang terdiri dari 3 butir pertanyaan, dengan rentang skor 1-4. Hasil perhitungan kemudian disusun berdasarkan kategori skor. Berdasarkan hasil perhitungan didapatkan tabel distribusi frekuensi pada tabel 2 .

Tabel 2. Distribusi frekuensi komponen konteks

\begin{tabular}{clcr}
\hline No. & Kategori & F & $(\%)$ \\
\hline 1 & sangat baik & 0 & 0 \\
\hline 2 & baik & 0 & 0 \\
\hline 3 & cukup baik & 47 & 83,93 \\
\hline 4 & kurang baik & 7 & 12,50 \\
\hline 5 & tidak baik & 2 & 3,57 \\
\hline & Jumlah & 56 & 100 \\
\hline
\end{tabular}

Berdasarkan tabel 2 distribusi frekuensi dapat diketahui sejumlah 47 responden (83.93\%) menyatakan program In-service Training guru SMK yang dilaksanakan di BLPT Yogyakarta terhadap kebutuhan guru dalam kategori cukup baik, 7 responden $(12,5 \%)$ dalam kategori kurang baik, sedangkan 2 responden (3.57\%) dalam kategori tidak baik. Hasil ini sesuai dengan penelitian yang dilakukan oleh Norwani, dkk. (2015) yang menyatakan terdapat hubungan antara kebutuhan pelatihan dengan kemampuan mengajar yang merupakan kompetensi proesional guru. Hasil penelitian ini juga sesuai dengan hasil penelitian yang dilakukan oleh Aziz, dkk (2016) yang menyatakan bahwa secara signifikan dampak pelatihan berpengaruh terhadap peningkatan kompetensi profesional guru. Berdasarkan hasil evaluasi konteks, dapat disimpulkan bahwa isi program In-service Training yang dilaksanakan di BLPT Yogyakarta sudah relevan dan cukup baik dalam memenuhi kebutuhan peserta.

Hasil ini sesuai dengan teori yang dikemukakan oleh Arikunto \& Jabar (2014, p.46) yang menyatakan bahwa evaluasi konteks berisi relevansi dan keterkaitan program dengan kebutuhan peserta dan tahapan paling dasar dalam menentukan tujuan. Teori lain yang mendukung dikemukakan oleh Roesken (2011, p.57) yang menyatakan program In-service Training sebaiknya dilaksanakan secara berkelanjutan dan sesuai dengan mata pelajaran yang diajarkan guru di sekolah, sehingga akan mempunyai dampak nyata pada peningkatan kompetensi guru dalam hal pengetahuan dan praktik, serta tingkat kepercayaan terhadap guru.

Penelitian ini juga telah membuktikan bahwa program In-service Training guru SMK di BLPT Yogyakarta mempunyai relevansi yang cukup baik dalam memenuhi kebutuhan peserta dan mampu memberi dukungan yang cukup tinggi bagi tercapainya tujuan program. Komponen input pada instrumen penelitian ini terdiri dari 4 sub komponen, yaitu: karakteristik peserta, instruktur, materi, dan sarana prasarana. Berdasarkan data yang diperoleh dari 56 responden yang terdiri dari 16 pertanyaan dengan rentang skor 1-4.

Berdasarkan hasil perhitungan yang kemudian disusun berdasarkan kategori skor diketahui sejumlah 47 responden $(83,93 \%)$ menyatakan input program terkait dengan karakteristik peserta, instruktur, materi, dan sarana prasarana cukup baik dalam mendukung keberhasilan program In-service Training dalam rangka peningkatan kompetensi guru SMK 
di BLPT Yogyakarta, 7 responden $(12,50 \%)$ dalam kategori kurang baik, sedangkan 2 responden $(3,57 \%)$ dalam kategori tidak baik.

Hasil data yang diperoleh untuk karakteristik peserta melalui 56 responden dengan 3 butir pertanyaan dengan rentang skor butir pertanyaan 1-4, kemudian disusun berdasarkan kategori skor. Berdasarkan hasil hitungan diperoleh tabel distribusi frekuensi pada tabel 3.

Tabel 3. Distribusi frekuensi karakteristik peserta

\begin{tabular}{llrr}
\hline No. & \multicolumn{1}{c}{ Kategori } & \multicolumn{1}{c}{ F } & \multicolumn{1}{c}{$(\boldsymbol{\%})$} \\
\hline 1 & sangat baik & 0 & 0 \\
\hline 2 & Baik & 1 & 1,79 \\
\hline 3 & cukup baik & 38 & 67,86 \\
\hline 4 & kurang baik & 13 & 23,21 \\
\hline 5 & tidak baik & 4 & 7,14 \\
\hline & Jumlah & 56 & 100
\end{tabular}

Berdasarkan tabel 3 distribusi frekuensi dapat diketahui sejumlah 1 responden $(1,79 \%)$ menyatakan program In-service Training guru SMK yang dilaksanakan di BLPT Yogyakarta sesuai dengan karakteristik peserta dan termasuk dalam kategori baik, sejumlah 38 responden $(67,86 \%)$ termasuk dalam kategori cukup baik, 13 responden $(23.21 \%)$ termasuk dalam kategori kurang baik, sedangkan sejumlah 4 responden $(7,14 \%)$ termasuk dalam kategori tidak baik.

Penelitian ini juga membuktikan bahwa peserta program In-service Training guru SMK di BLPT Yogyakarta memiliki kualifikasi akademik sesuai syarat yang ditentukan, namun masih terdapat beberapa guru yang mengampu mata pelajaran yang tidak sesuai dengan program yang diikuti. Hal ini dilakukan karena peserta yang telah terdaftar pada Program Inservice Training mengundurkan diri dengan alasan ada acara kedinasan yang mendadak harus diikuti. Meskipun demikian berdasarkan hasil data penelitian telah membuktikan bahwa karakteristik peserta memberi dukungan yang cukup tinggi bagi keberhasilan tercapainya tujuan program In-service Training guru SMK di BLPT Yogyakarta

Hasil data yang diperoleh tentang instruktur melalui 56 responden dengan 5 butir pertanyaan dengan rentang skor $1-4$ yang disusun berdasarkan kategori skor diperoleh hasil hitungan sesuai distribusi frekuensi pada tabel 4.

Tabel 4. Distribusi frekuensi komponen input tentang instruktur

\begin{tabular}{clrr}
\hline No & Kategori & \multicolumn{1}{c}{ F } & \multicolumn{1}{c}{$(\%)$} \\
\hline 1 & sangat baik & 0 & 0 \\
2 & Baik & 19 & 33,93 \\
3 & cukup baik & 36 & 64,29 \\
4 & kurang baik & 2 & 3,57 \\
5 & cukup baik & 0 & 0 \\
\hline & Jumlah & 56 & 100 \\
\hline
\end{tabular}

Berdasarkan tabel 4 distribusi frekuensi dapat diketahui sejumlah 19 responden $(33,93 \%)$ menyatakan bahwa instruktur memiliki dukungan terhadap keberhasilan program In-service Training guru SMK yang diselenggarakan di BLPT Yogyakarta dan termasuk dalam kategori baik, sejumlah 36 responden $(64,29 \%)$ dalam kategori cukup baik, dan 2 responden $(3,57 \%)$ dalam kategori kurang baik. Dukungan instruktur dalam keberhasilan program In-service Training meliputi kualifikasi akademik yang dimiliki instruktur, kompetensi, dan penguasaan materi. 
Hasil ini sesuai dengan teori yang dikemukakan oleh Kirkpatrick \& Krikpatrick (2008, p.3) yang menyatakan bahwa salah satu faktor penyebab keberhasilan suatu program pelatihan dalam mencapai tujuannya secara efektif adalah tersedianya instruktur yang memiliki kompetensi sesuai dengan program pelatihan yang diadakan. Teori lain yang mendukung hasil penelitian tentang dukungan instruktur pada program pelatihan dikemukakan oleh Noe (2005, p.3) yang menyatakan tujuan dari pelatihan adalah agar pegawai menguasai pengetahuan dan keterampilan yang didapatkan dalam program pelatihan untuk diterapkan sesuai bidang tugasnya masing-masing. Hal ini berarti bahwa pada suatu program pelatihan seorang instruktur harus memiliki kompetensi yang sesuai dengan program yang diadakan dan berkompeten di bidangnya

Berdasarkan data tentang materi pada komponen input dari 56 responden dengan 5 butir pertanyaan dengan rentang skor butir pertanyaan $1-4$ dan disusun dalam kategori skor, diperoleh hasil hitungan sebagaimana tabel distribusi frekuensi pada tabel 5.

Tabel 5. Distribusi frekuensi komponen input tentang materi

\begin{tabular}{cllc}
\hline No. & Kategori & F & $(\%)$ \\
\hline 1 & sangat baik & 0 & 0 \\
2 & Baik & 0 & 0 \\
3 & cukup baik & 50 & 89,29 \\
4 & kurang baik & 5 & 8,93 \\
5 & tidak baik & 1 & 1,79 \\
\hline & Jumlah & 56 & 100 \\
\hline
\end{tabular}

Berdasarkan tabel 5 distribusi frekuensi dapat diketahui sejumlah 50 responden (89.29\%) menyatakan bahwa materi yang diberikan pada peserta relevan dengan program Inservice Training guru SMK yang diselenggarakan di BLPT Yogyakarta dan termasuk dalam kategori cukup baik, sejumlah 5 responden $(8,93 \%)$ termasuk dalam kategori kurang baik, sedangkan 1 responden $(1,79 \%)$ termasuk dalam kategori tidak baik.

Penelitian ini juga membuktikan bahwa materi yang digunakan pada program In-service Training guru SMK di BLPT Yogyakarta relevan dengan program pelatihan, mudah dipahami dan materi tersebut mampu menambah pengetahuan serta keterampilan yang dimiliki oleh peserta program. Hal ini dapat diartikan bahwa materi yang digunakan memberi dukungan yang cukup tinggi bagi keberhasilan tercapainya tujuan program In-service Training guru SMK di BLPT Yogyakarta

Berdasarkan data pada komponen input mengenai sarana dan prasarana dari 56 responden dengan 5 butir pertanyaan dengan rentang skor butir pertanyaan $1-4$ yang disusun dalam kategori skor, diperoleh hasil hitungan sesuai distribusi frekuensi pada tabel 6.

Tabel 6. Distribusi frekuensi sarana dan prasarana

\begin{tabular}{clrr}
\hline No. & \multicolumn{1}{c}{ Kategori } & F & $(\%)$ \\
\hline 1 & sangat baik & 0 & 0 \\
2 & Baik & 5 & 8,93 \\
3 & cukup baik & 51 & 91,07 \\
4 & kurang baik & 0 & 0 \\
5 & tidak baik & 0 & 0 \\
\hline & Jumlah & 56 & 100 \\
\hline
\end{tabular}

Berdasarkan tabel 6 distribusi frekuensi dapat diketahui 5 responden $(8,93 \%)$ menyatakan terdapat dukungan sarana dan prasarana dalam penyelenggaraan program Inservice Training guru SMK di BLPT Yogyakarta termasuk dalam kategori baik, sedang 51 responden $(91,07 \%)$ termasuk dalam kategori cukup baik. 
Penelitian ini juga membuktikan bahwa sarana dan prasarana yang disediakan di lokasi pelatihan (BLPT Yogyakarta) telah mampu dengan cukup baik memenuhi kebutuhan peserta. Sarana dan prasarana yang disediakan meliputi: ruang teori, ruang/tempat praktik, peralatan praktik, sumber belajar, dan fasilitas lainnya (antara lain: konsumsi, P3K, tempat ibadah, toilet). Hal ini juga membuktikan bahwa saran dan prasarana telah memberi dukungan yang cukup tinggi bagi tercapainya tujuan program In-service Training guru SMK di BLPT Yogyakarta

Berdasarkan hasil analisis data penelitian pada komponen input dapat disimpulkan input program telah cukup baik dalam mendukung keberhasilan program In-service Training guru SMK di BLPT Yogyakarta. Hasil ini sesuai dengan penelitian yang dilakukan oleh Pirmehtar \& Omidian (2013) yang menyatakan efek program In-service Training untuk meningkatkan pengetahuan profesional sangat tinggi jika direncanakan sesuai kebutuhan guru, komdisi, kemajuan ilmu pengetahuan serta dukungan fasilitas yang tersedia dan dilakukan secara terus menerus dan berkelanjutan. Hasil penelitian lain yang sesuai adalah penelitian dilakukan oleh Rusdin (2017) yang menunjukkan pendidikan dan pelatihan memberi kontribusi yang berarti bagi para guru yang masih kurang memenuhi standar pendidikan dan pengajaran.

Komponen proses pada penelitian ini terdiri dari 5 sub komponen, yaitu: jadwal kegiatan, partisipasi peserta pelatihan, media pembelajaran, metode pembelajaran, dan evaluasi pembelajaran. Berdasarkan data yang diperoleh dari 56 responden yang terdiri dari 13 pertanyaan dengan rentang skor 1-4, sehingga diperoleh skor tertinggi 4 dan skor terendah 1. Berdasarkan hasil perhitungan yang kemudian disusun berdasarkan kategori skor diketahui sejumlah 53 responden $(94,6 \%)$ menyatakan proses dalam program In-service Training telah berlangsung dengan cukup baik terkait jadwal, partisipasi peserta, media, metode, dan evaluasi pembelajaran, sedangkan 3 responden $(5,4 \%)$ dalam kategori kurang baik.

Hasil perhitungan pada komponen proses tentang jadwal dari 56 responden dengan 2 butir pertanyaan dengan rentang skor butir $1-4$ kemudian disusun sesuai dengan kategori diperoleh tabel distribusi frekuensi pada tabel 7.

\begin{tabular}{clrr}
\multicolumn{4}{l}{ Tabel 7. Distribusi frekuensi jadwal kegiatan } \\
\hline No. & \multicolumn{1}{c}{ Kategori } & \multicolumn{1}{c}{ F } & \multicolumn{1}{c}{ (\%) } \\
\hline 1 & sangat baik & 0 & 0 \\
2 & baik & 15 & 26,79 \\
3 & cukup baik & 36 & 64,29 \\
4 & kurang baik & 5 & 8,93 \\
5 & tidak baik & 0 & 0 \\
\hline & Jumlah & 56 & \multicolumn{1}{c}{100} \\
\hline
\end{tabular}

Berdasarkan tabel 7 distribusi frekuensi dapat diketahui 15 responden (26,79\%) menyatakan bahwa jadwal kegiatan sesuai dengan pelaksanaan program In-service Training guru SMK di BLPT Yogyakarta dan termasuk dalam kategori baik, 36 responden $(64,29 \%)$ termasuk dalam kategori cukup baik, dan 5 responden $(8,93 \%)$ termasuk dalam kategori tidak baik.

Penelitian ini membuktikan bahwa jadwal yang digunakan dalam program In-service Training telah memberi alokasi waktu yang cukup baik pada setiap kegiatan yang dilakukan peserta. Hal ini berarti bahwa jadwal yang digunakan memberi dukungan yang cukup tinggi bagi tercapainya tujuan program In-service Training guru SMK di BLPT Yogyakarta

Berdasarkan data komponen proses tentang partisipasi peserta dari 56 responden dengan 2 butir pertanyaan dengan rentang skor butir pertanyaan 1- 4, kemudian disusun berdasarkan kategori skor diperoleh hasil hitungan sesuai distribusi frekuensi pada tabel 8 . 
Tabel 8. Distribusi frekuensi partisipasi peserta pelatihan

\begin{tabular}{clrr}
\hline No. & Kategori & F & \multicolumn{1}{c}{$(\%)$} \\
\hline 1 & sangat baik & 0 & 0 \\
2 & Baik & 2 & 3,57 \\
3 & cukup baik & 32 & 57,14 \\
4 & kurang baik & 17 & 30,38 \\
5 & tidak baik & 5 & 6,67 \\
\hline & Jumlah & 56 & 100 \\
\hline
\end{tabular}

Berdasarkan tabel 8 distribusi frekuensi diketahui 2 responden $(3,57 \% \%)$ menyatakan berpartisipasi aktif pada pelaksanaan program In-service Training dan berada dalam kategori baik, sejumlah 32 responden $(57,14 \%)$ termasuk dalam kategori cukup baik, 17 responden $(30,38 \%)$ termasuk dalam kategori kurang baik, sedangkan 5 responden $(6,67 \%)$ termasuk dalam kategori tidak baik.

Penelitian ini juga membuktikan bahwa peserta program In-service Training guru SMK di BLPT Yogyakarta telah memberi dukungan yang cukup tinggi bagi keberhasilan tercapainya tujuan program. Hal lain yang didapat pada penelitian ini adalah beberapa peserta program tidak dapat aktif mengikuti kegiatan program In-service Training karena alasan kedinasan. Hal ini terjadi karena keterlambatan pihak penyelenggara dalam menyampaikan pemberitahuan pada instansi terkait dalam hal ini sekolah. Berdasarkan pengalaman tersebut, maka pihak penyelenggara wajib berusaha untuk membuat jadwal yang sesuai dengan kebutuhan guru, sehingga peserta program dapat berpartisipasi secara aktif dan mengikuti kegiatan sesuai alokasi waktu yang diselenggarakan

Hasil data komponen proses tentang media pembelajaran dari 56 responden dengan 3 butir pertanyaan dengan rentang skor butir pertanyaan $1-4$ dan disusun berdasarkan kategori skor diperoleh hasil perhitungan sebagaimana distribusi frekuensi pada tabel 9.

Tabel 9. Distribusi frekuensi media pembelajaran

\begin{tabular}{clrr}
\hline No. & Kategori & F & \multicolumn{1}{c}{$(\%)$} \\
\hline 1 & sangat baik & 0 & 0 \\
2 & Baik & 2 & 3,57 \\
3 & cukup baik & 47 & 83,93 \\
4 & kurang baik & 7 & 12,50 \\
5 & tidak baik & 0 & 0 \\
\hline & Jumlah & 56 & 100 \\
\hline
\end{tabular}

Berdasarkan tabel 9 distribusi frekuensi diketahui 2 responden $(3,57 \%)$ menyatakan ketersediaan dan kesesuaian media pembelajaran dalam program In-service Training guru SMK di BLPT Yogyakarta serta dikategorikan baik, 47 responden $(83,93 \%)$ dinyatakan dalam kategori cukup baik, dan 7 responden $(12,50 \%)$ dinyatakan dalam kategori kurang baik.

Penelitian ini juga membuktikan bahwa media belajar yang digunakan pada program Inservice Training guru SMK di BLPT Yogyakarta dalam kondisi cukup baik dengan jenis yang cukup beragam. Hal ini juga membuktikan bahwa media belajar yang digunakan dalam pembelajaran telah memberi dukungan yang cukup tinggi bagi keberhasilan tercapainya tujuan program In-service Training guru SMK di BLPT Yogyakarta.

Berdasarkan data penelitian komponen proses tentang metode pembelajaran dari 56 responden dengan 3 butir pertanyaan dengan rentang skor butir pertanyaan $1-4$ yang disusun berdasarkan kategori skor diperoleh hasil perhitungan sebagaimana distribusi frekuensi pada tabel 10 . 
Tabel 10. Distribusi frekuensi metode pembelajaran

\begin{tabular}{clcc}
\hline No. & Kategori & F & $(\%)$ \\
\hline 1 & sangat baik & 0 & 0 \\
2 & Baik & 4 & 7,14 \\
3 & cukup baik & 52 & 92,86 \\
4 & kurang baik & 0 & 0 \\
5 & tidak baik & 0 & 0 \\
\hline & Jumlah & 56 & 100 \\
\hline
\end{tabular}

Berdasarkan tabel 10 distribusi frekuensi diketahui 4 responden $(7,14 \%)$ menyatakan metode yang digunakan oleh instruktur bervariasi dan sesuai dengan tujuan pembelajaran dalam program In-service Training guru SMK di BLPT Yogyakarta dan dinyatakan dalam kategori baik, dan 52 responden $(92,86 \%)$ termasuk dalam kategori cukup baik.

Penelitian ini membuktikan bahwa metode mengajar yang digunakan instruktur pada program In-service Training cukup beragam, sesuai dengan materi dan tujuan pembelajaran. Hal ini dapat diartikan metode mengajar yang digunakan instruktur memberi dukungan yang cukup tinggi terhadap keberhasilan pencapaian tujuan program In-service Training guru SMK di BLPT Yogyakarta

Hasil data komponen proses tentang evaluasi pembelajaran dari 56 responden dengan 3 butir pertanyaan dengan rentang skor butir pertanyaan $1-4$ yang disusun berdasarkan kategori skor diperoleh hasil hitungan sebagaimana distribusi frekuensi pada tabel 11.

Tabel 11. Distribusi frekuensi evaluasi pembelajaran

\begin{tabular}{clrr}
\hline No. & \multicolumn{1}{c}{ Kategori } & $\mathrm{F}$ & $(\%)$ \\
\hline 1 & sangat baik & 0 & 0 \\
2 & Baik & 0 & 0 \\
3 & cukup baik & 42 & 75 \\
4 & kurang baik & 14 & 25 \\
5 & tidak baik & 0 & 0 \\
\hline & Jumlah & 56 & 100 \\
\hline
\end{tabular}

Berdasarkan tabel 11 distribusi Frekuensi diketahui 42 responden $(75 \%)$ menyatakan evaluasi relevan dengan materi yang diberikan pada program In-service Training guru SMK di BLPT Yogyakarta, termasuk dalam kategori cukup baik, dan 14 responden (25\%) termasuk dalam kategori kurang baik.

Penelitian ini juga membuktikan bahwa evaluasi pembelajaran yang digunakan pada program In-service Training guru SMK di BLPT Yogyakarta sudah cukup baik. Hal ini juga membuktikan bahwa evaluasi pembelajaran yang digunakan telah memberi dukungan yang cukup tinggi terhadap keberhasilan pencapaian tujuan program In-service Training guru SMK di BLPT Yogyakarta

Komponen produk pada penelitian ini terdiri dari 1 sub komponen, yaitu: manfaat program bagi peserta. Berdasarkan data yang diperoleh dari 56 responden yang terdiri dari 4 pertanyaan dengan rentang skor 1-4 yang disusun berdasarkan kategori skor diketahui sejumlah 49 responden $(87,5 \%)$ menyatakan komponen produk telah cukup baik memberi manfaat bagi peserta program In-service Training guru SMK di BLPT Yogyakarta. Sejumlah 6 responden $(10,7 \%)$ berada dalam kategori baik, dan 1 responden $(1,8 \%)$ berada dalam kategori kurang baik, selengkapnya dapat dilihat pada tabel 12. Berdasarkan dokumen penilaian evaluasi pembelajaran tahap akhir diketahui 3 dari 13 peserta kompetensi keahlian autocad mendapat nilai 60 dan termasuk dalam rentang nilai 56-65 yang setara dengan nilai C/cukup (Arikunto, 2010). 
Tabel 12. Distribusi frekuensi manfaat program

\begin{tabular}{clrr}
\hline No. & Kategori & F & \multicolumn{1}{c}{$(\%)$} \\
\hline 1 & sangat baik & 0 & 0 \\
2 & Baik & 6 & 10,71 \\
3 & cukup baik & 49 & 87,50 \\
4 & kurang baik & 1 & 1,79 \\
5 & tidak baik & 0 & 0 \\
\hline & Jumlah & 56 & 100 \\
\hline
\end{tabular}

Berdasarkan tabel 12 distribusi frekuensi diketahui 49 responden $(87,50 \%)$ menyatakan bahwa program In-service Training guru SMK di BLPT Yogyakarta bermanfaat bagi pembelajaran siswa di sekolah, mampu meningkatkan pengetahuan dan keterampilan guru serta meningkatan life skill siswa. Berdasarkan mayoritas jawaban responden $(87,50 \%)$ termasuk dalam kategori cukup baik, 6 responden $(10,71 \%)$ termasuk dalam kategori baik, dan 1 responden $(1,79 \%)$ termasuk dalam kategori kurang baik.

Hasil penelitian ini sesuai dengan penelitian yang dilakukan oleh Uysal (2012) yang menyimpulkan bahwa hasil dari program In-service Training tergantung dari konteks, input, dan proses yang berlangsung pada pelatihan. Hasil penelitian ini juga sesuai dengan pendapat yang dikemukakan oleh Kiripatrick \& Krikpatrick (2008, p.3) yang menyatakan agar program pelatihan dapat berlangsung secara efektif mencapai tujuan, maka dalam perencanaannya perlu dipertimbangkan faktor konteks, input, proses yang antara lain terkait perencanaan program yang sesuai kebutuhan peserta, materi, instruktur, peserta yang memenuhi standar dan syarat yang telah ditentukan, sarana prasarana, jadwal kegiatan.

\section{SIMPULAN}

Berdasarkan hasil analisis data dapat disimpulkan bahwa pelaksanaan program In-service Training guru SMK di BLPT Yogyakarta berada dalam kategori cukup baik. Hal ini dilihat dari diskripsi data hasil penelitian bahwa $87,5 \%$ responden menyatakan program In-service Training guru SMK di BLPT Yogyakarta cukup bermanfaat dalam meningkatkan pengetahuan dan keterampilan peserta. Berdasarkan rerata skor mencapai 3,17 dengan kategori baik, namun berdasar dokumen penilaian masih terdapat 3 peserta program keahlian Autocad yang memiliki nilai 60 dengan kategori cukup.

Berdasarkan hasil penelitian secara umum dapat disimpulkan bahwa program In-service Training guru SMK di BLPT Yogyakarta masih perlu perbaikan pada komponen input dan komponen proses. Perbaikan komponen input pada penelitian ini adalah karakteristik peserta, dimana mata pelajaran yang diampu peserta program In-service Training tidak sesuai dengan kompetensi yang berikan pada program, sehingga tidak mendapat hasil maksimal setelah mengikuti program. Perbaikan komponen proses pada penelitian ini adalah pada jadwal dan partisipasi peserta. Jadwal yang diberikan oleh BLPT belum sepenuhnya sesuai dengan kebutuhan guru, sedangkan pada penelitian ini beberapa peserta program kurang berpartisipasi secara aktif dalam pembelajaran. Hal ini menyebabkan kurangnya pemahaman peserta program terhadap materi yang diberikan. Keadaan ini mengakibatkan produk yang dihasilkan tidak maksimal, sehingga dapat disimpulkan hasil program In-service Training berjalan cukup baik. 


\section{DAFTAR PUSTAKA}

Arikunto, S. (2010). Prosedur penelitian: suatu pendekatan praktik. Jakarta: PT. Rineka Cipta.

Arikunto, S., \& Jabar, C. S. A. (2014). Evaluasi program pendidikan: Pedoman teoritis praktis bagi mahasiswa dan praktisi pendidikan. Jakarta: P.T. Bumi Aksara.

Aziz, F., \& Akhtar, M. M. S. (2016). Impact of training on teachers competencies at higher education level in Pakistan. ProQuest.

Gumbo, M., Makgato, M., \& Müller, H. (2010). The impact of in-service technology training programmes on technology teachers. The Journal of Technology Studies.

Hamalik, O. (2014). Kurikulum dan pembelajaran. Jakarta: PT. Bumi Aksara.

Jahangir, S. F., Saheen, N., Kazmi, S. F. (2012). Inservice training: a contributory factor influenzing teachers' performance. International Journal of Academic Research in Progressive Education and Development, $1(1)$.

Krikpatrick, D. L., \& Kirkpatrick, J. D. (2008). Evaluating Training Programs the four levels. (3 ${ }^{\text {nd }}$ ed). San Fransisco: Berrett-Koehler Publishers. Inc.

Napitupulu, E. L. (7 Juli 2015). Mutu guru belum menggembirakan. Tersedia di: https://www.kompas.com/

Noe, R. A. (2005). Employee training and development $\left(3^{\text {nd }} \mathrm{Ed}\right)$. Singapore: McGraw-Hill.

Norwani, N. M., Ismail, K., Mansor, M., Yusof, H., Tamby, C. I., \& Yusof, R. (2015). Relationship between inservice training and teaching skills with student achievement. International Conference on Education and Social Sciences $2^{\text {nd }}$. Tersedia di: www.ocerint.org/intcessis_e-publication/papers/223.

Pirmehtar, S., \& Omidian, F. (2013). The effectiveness of in-service training courses on the sixth grade teachers of Andimeshk City. World Scientific News(2014)1-9.EISSN23922192.

Roesken, B. (2011). Hidden dimensions in the profesional development of mathematics teachers: In-service education for and with teachers. Rotterdam: Sense Publishers. (Bookfi).

Rusdin. (2017). Pendidikan dan pelatihan sebagai sarana peningkatan kompetensi guru di SMP Negeri 02 linggang bigung. Jurnal Administrative Reform, 5(4)

Thoha, C. (2003). Teknik evaluasi pendidikan. Jakarta: Grafindo Persada. 